\title{
The Effect of Pregnancy on Intertemporal Choice and Its Mechanism
}

\author{
Xin Li \\ Management School, Jinan University, Guangzhou, China \\ Email:413013070@qq.com
}

How to cite this paper: Li, X. (2016). The Effect of Pregnancy on Intertemporal Choice and Its Mechanism. Psychology, 7, 1326-1334.

http://dx.doi.org/10.4236/psych.2016.710134

Received: August 29, 2016

Accepted: September 19, 2016

Published: September 22, 2016

Copyright $\odot 2016$ by author and Scientific Research Publishing Inc.

This work is licensed under the Creative

Commons Attribution International

License (CC BY 4.0).

http://creativecommons.org/licenses/by/4.0/

\begin{abstract}
Pregnancy has been considered a special period with cognitive defect and unstable emotion. However, physiological and psychological changes jointly reshape the brain of pregnant women, which makes them more patient and prefer future outcomes. Specifically, they become more future-orientated, self-controlled and more positive to the future. These phenomena can be accounted for evolution perspective and construal level theory. Furthermore, we recommend that future researches pay attention to the effect of pregnancy on intertemporal choice in different domains and the relevant influence of expectant fathers on delay discounting.
\end{abstract}

\section{Keywords}

Pregnant Women, Future Orientation, Anticipated Emotion, Self-Control, Intertemporal Choice

\section{Introduction}

Pregnancy is one of the most important periods in woman's life time. Although previous studies suggest that pregnancy results in a mild impairment in general cognitive functioning and in a variety of memory tasks, and in a moderate deficit in processing speed (Buckwalter et al., 1999; Crawley, Dennison, \& Carter, 2003; Christensen, Leach, \& Mackinnon, 2010), pregnancy may have some positive effects such as spatial memory and identification of novel stimulus (Love et al., 2005; Anderson \& Rutherford, 2012). In this period, plenty of cognitive changes have taken place, which may exert a great influence on their decision-making.

Intertemporal choice is one of the decisions making that involve outcomes at different points in time. For example, decisions about whether or not to stop smoking cigarettes involve trade-off between the short-term pleasure or long-term benefits. A perva- 
sive phenomenon that people prefer sooner and smaller reward to later and larger reward called time discounting (or delay discounting). But different people in different situations perform distinctly. It can be moderated by several factors, including the framework of background and options and personality traits or status. Recently, scholars have come to put more weight on impact of individual differences on delay discounting (Shamosh \& Gray, 2008; Kim \& Zauberman, 2009; Sun, Li, Bonini, \& Su, 2012). Researchers have considered future orientation, anticipated emotions and self-control will further reduce delay discounting (Lumpkin \& Brigham, 2011). By searching relevant literature, we found pregnant women had advantages over these aspects. When a female becomes pregnant, she is more likely to picture wonderful future with her baby and care much more about behaviors of herself so that she can give birth to a healthy baby. Thus, we review the related studies and make a summary of pregnancy and intertemporal choice. Then we briefly illustrate the mechanism and recommend that future researches pay attention to the effect of pregnancy on intertemporal choice in different domains and the relevant influence of expectant fathers on delay discounting.

\section{Pregnancy and Intertemporal Choice}

Pregnancy will reduce delay discounting by changes from cognition, emotion and volition respectively. Specifically, pregnant women would have higher future orientation and self-control level, and more positive anticipated emotion.

\subsection{Pregnancy and Future Orientation}

Future orientation has been described as the extent to which potential future consequences of an action influence current decision outcomes. It was measured by "Consideration of Future consequences" scale, a measure of the extent to which people consider distant versus immediate consequences of possible behaviors (Strathman et al., 1994). Researchers found future orientation can effectively predict delay discounting (Steinberg, Graham, O’Brien, Woolard, Cauffman, \& Banich, 2009; Rabinovich, Morton, \& Postmes, 2010), saving or long-term financial decisions (Webley \& Nyhus, 2006; Howlett, Kees, \& Kemp, 2008) and undesirable behaviors such as drug use and gambling (Reynolds, 2006).

Li, Peng and Xiong (2015) found that pregnant women had lower discount rate compared to non-pregnant women. In addition, future orientation played a completely mediating role between pregnancy and delay discounting. Researchers had conducted a quasi-experiment design and an experiment design to reach this conclusion, which successfully excluded the influence of demography and physiology. In study 1 , participants of real-pregnant women and non-pregnant women were asked to complete the CFC scale and task of delay discounting by Wang and Dvorak (2010). In study 2, participants of female undergraduates were asked completed the same procedure as study 1 before half of them were activated as pregnant by watching videos about antenatal training. Pregnant women and "pregnant" undergraduates had higher score of future 
orientation and lower discount rate.

Due to having a baby, pregnant women are likely to imagine future times frequently and hence increase their future orientation, which leads to lower discount rate.

\subsection{Pregnancy and Anticipated Emotion}

Anticipated emotion, an important aspect of the feedback theory of emotion is that people learn to anticipate emotional outcomes and adjust their behavior accordingly (Baumeister, DeWall, Vohs, \& Alquist, 2010), contains positive emotion and negative emotion. Researchers have found anticipated emotions can differently predict delay discounting (Liu, Feng, Chen, \& Li, 2013). In previous studies, researchers found episodic prospection can reduce delay discounting by modulate the neutral network of imaginary prospection (Peters \& Büchel, 2010). However, episodic prospection may involve the valence of future emotions, which has an impact on delay discounting (Loewenstein \& Lerner, 2003). By manipulating the emotion valence of episodic prospection, Liu and his colleagues suggested that positive emotion made individuals tend to choose delayed rewards, while negative emotion made individuals tend to choose immediate rewards. Choice preference was unchanged by only imaging events with neutral emotion. Thus, the valence of imaged future events' emotion might play an important role in individuals' intertemporal choice.

Humans can vividly envisage possible future episodes. For pregnant women, they are good at imaging the pictures of their baby's smile and looking forward to becoming a mother, especially for the first-time pregnancy. First-time mothers are likely experience more positive emotions than negative emotions (Harwood, McLean, \& Durkin, 2007). Harwood et al. (2007) investigated 71 first-time mothers who completed questionnaires which assessed their expectations of caring for their infant and the influence parenthood would have on their well-being during pregnancy and at 4 months postpartum. Results found that most women's expectations were matched or exceeded by their parenting experiences.

Powdthavee (2009) also found expected mothers have overly optimistic expectations about parenthood and they tend to conjure up pictures of healthy babies, handsome boys or gorgeous-looking girls who are flawless in every way, which may easily lead to a focusing illusion.

In addition to future orientation, pregnant women expect their first child with positive anticipation, which may reduce delay discounting.

\subsection{Pregnancy and Self-Control}

Self-control is the exertion of control over the self by the self (Muraven \& Baumeister, 2000). It can be measured by different forms such as SCS scale, self-control task including dual task paradigm, delay of gratification task, conflict resolution task and so on. Self-control can effectively predict delay discounting (Figner, Knoch, Johnson, Krosch, Lisanby, Fehr, \& Weber, 2010) and impulsive behaviors such as drug use (Madden, Petry, Badger, \& Bickel, 1997), cigarette smoking (Bickel, Odum, \& Madden, 
1999).

Women would make some behavioral changes to get a better life style since they have become pregnant. They would keep a balanced diet and regular exercises, use less cosmetics and even quit alcohol drinking and cigarette smoking for the sake of health of babies (Sevin \& Ladwein, 2008). These self-regulations show that pregnant women seem to be more self-controlled.

In addition to behavioral changes, there are some physiological changes in pregnancy. Pregnant women have higher level of glucose than non-pregnant women, which may make a contribution to self-control behavior. Self-control relies on a limited energy source, that is to say, an initial act of self-control consumes some energy source that is needed for later attempts at self-control. Researchers found glucose, as a limited energy source, have a profound impact on self-control (Gailliot \& Baumeister, 2007). Participants with higher level of glucose had stronger ability of attention control (Gailliot, Baumeister et al., 2007), a basic form of self-control, and more social desirable behaviors (Matykiewicz, La Grange, Vance et al., 1997).

From what we illustrate above, we can deduce that pregnant women with higher level of glucose and child-orientation will have larger self-control capacity, and therefore result in low discount rate.

\section{Mechanism}

Pregnant women have higher level of future orientation, more positive anticipation and self-control behaviors. And these distinct changes can be accounted for evolution perspective and construal level theory.

\subsection{Evolutionary Prospective}

Female mammals would change their behaviors and motivation radically since they have been pregnant. They had to adapt to new demands from the offspring and take a risk of investment loss of energy and gene (Kinsley \& Lambert, 2006). From the perspective of evolutionary, the most important challenge for female is to make sure that the gene can be carried from generation to generation. The evolution of maternal behavior facilitates to the success. Kinsley and Lambert (2008) found all female animals, including rats and humans, have made a behavioral change during pregnancy. When mammals were arisen from reptiles, their reproductive strategy has changed from oviposition to cave protection, the latter of which would prompt plenty of hormones to inspire the brain of beneficial behaviors. Actually, hormones induced in pregnancy prompt mPOA in participation of birth and maternal behaviors and after birth, mPOA neurons direct mothers' attention and motivation to babies for caring.

Recent experiments have shown that mother rats outperformed virgins in navigating mazes and capturing prey, because mother rats had a strong will to look for foods frequently for babies even it is risky. Besides, they were easier to leave the cave for less fear and anxiety, and make a faster reaction with hostile surroundings. In fact, most mammals share the same maternal behavior which is one of main drivers of development of 
the mother's brain. In addition, the brain changes induced by hormone may enhance a mother rat's foraging abilities, giving her babies a better chance of survival. What is more, the cognitive benefits seem to be long-lasting, persisting until the mother rats enter old age (Love et al., 2005).

Although studies found that mammals have similar neutral mechanism with humans while in pregnancy, humans are unique in psychological changes. Mercer (2004) indicated that pregnant women would get through mother identity by self-commitment, until they were confident and were able to cope with difficulties. Besides, pregnant women were more likely to save money for future needs (Moran et al., 2006). For health of babies and themselves, they would quit alcohol drinking and cigarette smoking. All these planning behavior are mainly prepared for their offspring so that gene can be survived.

\subsection{Construal Level Theory}

Construal level theory suggests that perceptions of temporal distance systematically alter the way future events are construed and thus, influence the evaluation and choices related to those events (Trope \& Liberman, 2003). According to temporal construal theory, the cognitive representation of delayed outcomes is dominated by high-level attributes, while the construal of immediate outcomes is dominated by low-level attributes. Thus, an option that is rich in high-level attributes but poor in low-level attributes will be attractive in distance, but unattractive in proximity (Soman et al., 2005). It may be one of reasons why people are more likely to choose sooner but smaller rewards. So if the remote attributes were made proximal and concrete, people may less discount the larger but longer rewards.

Kees (2011) had made future health risk more proximal (e.g., body damage happens just two hours after consumption of a cigarette smoking), so that the consumers were more likely to take the risk seriously and engage in preventive behaviors than facing with distant health risk (e.g., body damage happens over time after consumption of a cigarette smoking).

People are capable of thinking about the future, especially for those who are hopeful about future times (Pyone \& Isen, 2011). Distant rewards seem unattractive to ordinary women but pregnant women. Women in pregnancy constantly think about how healthy and beautiful when their babies were born. Specifically, they image the smiling face and energetic body never missing a detail, which made a vague future seem to be more concrete and lower level construal. In this way, pregnant women may weigh present as important as future, which result in ineffectiveness of temporal dimension in intertemporal choice. Hence, they focus on money dimension and incline to the larger rewards.

Physical cognition theory emphasizes the role of body in cognitive process of organism. The body structure, sensory and motor system determines how we perceive the world and the way we perceive (Shapiro, 2007). In this case, the physical and chemical changes in female body would reshape the cognitive style of pregnant women. 


\section{Future Direction}

Although studies of influence of pregnant women on intertemporal choice were achieved by some researchers, there are still some areas deserved to dig in.

\subsection{The Effect of Pregnancy on Intertemporal Choice in Different Domains}

In addition to money discounting, intertemporal choice has different domains such as green discounting and health discounting, which are common in our daily life. Although we advocate environmental protection, the government and individuals still destroy the earth to an extent just for some convenience. Or people can't stop eating junk food, smoking and over-drinking only for momentary happiness though some of them had promised they would quit. All of them have discounted future greatly, which is harmful to their happiness in the long-term.

As researches proved, human discounted future less in environmental protection and health compared to money (Chapman, 1996; Hardisty \& Weber, 2009). In this way, pregnant women discounting future less in money will probably have the similar choice in health, environmental protection and other domains. In other words, pregnant women may care more about future environment and health, which suggests they have stronger ability of planning and execution.

\subsection{Expectant Fathers and Delay Discounting}

Pregnant women preferred less discounting rate because they thought a lot about future. And their husbands had the same tendency of expecting the future. When expectant fathers knew they would have babies, they may become hard-working to make a living for raising their unborn babies. In this way, they may be much more willing to wait for larger money.

Besides the assumption, Abraham (2014) and his colleagues found that fathers had the similar parental brain response with mothers, including emotional processing network and mentalizing network that are sensitive to infant. Specifically, mothers showed greater activation in emotion processing structures, which rapidly detects salient and survival-related cues and enables parents to immediately respond to infant distress. As for fathers, they displayed greater activation in mentalizing network, which plays an important role in social understanding and cognitive empathy, and is already activated during the parents' first weeks of parenting, and enables parents to cognitively represent infant states, predict infant needs, and plan future care-giving.

For example of last year, Facebook CEO Mark Zuckerberg gave away 99\% of shares to charity just for celebrating birth of daughter, which was got "likes" over 36 thousand times. Recently, Cronqvist and Yu (2016) had found that a CEO who has a female child increased a firm's corporate social responsibility rating by about $11.9 \%$ compared to a median firm, the effect being about one third of the effect of an executive herself being female. They also found the social responsibility was not related to quantity of daughters, which means the changes will last once they know a lovely baby girl is coming. So 
we can see that having children would reshape both parents' brain, which makes them more patient and prefer future outcomes.

\section{References}

Abraham, E., Hendler, T., Shapira-Lichter, I., Kanat-Maymon, Y., Zagoory-Sharon, O., \& Feldman, R. (2014). Father's Brain Is Sensitive to Childcare Experiences. Proceedings of the National Academy of Sciences, 111, 9792-9797. http://dx.doi.org/10.1073/pnas.1402569111

Anderson, M. V., \& Rutherford, M. D. (2012). Cognitive Reorganization during Pregnancy and the Postpartum Period: An Evolutionary Perspective. Evolutionary Psychology, 10, 659-687. http://dx.doi.org/10.1177/147470491201000402

Baumeister, R. F., DeWall, C. N., Vohs, K. D., \& Alquist, J. L. (2010). Does Emotion Cause Behavior (Apart from Making People Do Stupid, Destructive Things). Then a Miracle Occurs: Focusing on Behavior in Social Psychological Theory and Research, 119, 12-27. http://dx.doi.org/10.1007/PL00005490

Bickel, W. K., Odum, A. L., \& Madden, G. J. (1999). Impulsivity and Cigarette Smoking: Delay Discounting in Current, Never, and Ex-Smokers. Psychopharmacology, 146, 447-454.

Buckwalter, J. G., Stanczyk, F. Z., McCleary, C. A., Bluestein, B. W., Buckwalter, D. K., Rankin, K. P. et al. (1999). Pregnancy, the Postpartum, and Steroid Hormones: Effects on Cognition and Mood. Psychoneuroendocrinology, 24, 69-84. http://dx.doi.org/10.1016/S0306-4530(98)00044-4

Chapman, G. B. (1996). Temporal Discounting and Utility for Health and Money. Journal of $E_{X}$ perimental Psychology: Learning, Memory, and Cognition, 22, 771-791. http://dx.doi.org/10.1037/0278-7393.22.3.771

Christensen, H., Leach, L. S., \& Mackinnon, A. (2010). Cognition in Pregnancy and Motherhood: Prospective Cohort Study. The British Journal of Psychiatry, 196, 126-132. http://dx.doi.org/10.1192/bjp.bp.109.068635

Crawley, R. A., Dennison, K., \& Carter, C. (2003). Cognition in Pregnancy and the First Year Post-Partum. Psychology and Psychotherapy: Theory, Research and Practice, 76, 69-84. http://dx.doi.org/10.1348/14760830260569265

Cronqvist, H., \& Yu, F. (2016). Shaped by Their Daughters: Executives, Female Socialization, and Corporate Social Responsibility. In 6th Miami Behavioral Finance Conference.

Figner, B., Knoch, D., Johnson, E. J., Krosch, A., Lisanby, S. H., Fehr, E., \& Weber, E. U. (2010). Lateral Prefrontal Cortex and Self-Control in Intertemporal Choice. Nature Neuroscience, 13, 538-539. http://dx.doi.org/10.1038/nn.2516

Gailliot, M. T., \& Baumeister, R. F. (2007). The Physiology of Willpower: Linking Blood Glucose to Self-Control. Personality and Social Psychology Review, 11, 303-327. http://dx.doi.org/10.1177/1088868307303030

Gailliot, M. T., Baumeister, R. F., DeWall, C. N., Maner, J. K., Plant,E. A., Tice, D. M. et al. (2007). Self-Control Relies on Glucose as a Limited Energy Source: Willpower Is More than a Metaphor. Journal of Personality and Social Psychology, 92, 325-336. http://dx.doi.org/10.1037/0022-3514.92.2.325

Hardisty, D. J., \& Weber, E. U. (2009). Discounting Future Green: Money versus the Environment. Journal of Experimental Psychology: General, 138, 329-340.

http://dx.doi.org/10.1037/a0016433

Harwood, K., McLean, N., \& Durkin, K. (2007). First-Time Mothers' Expectations of Parenthood: What Happens When Optimistic Expectations Are Not Matched by Later Experiences? Deve- 
lopmental Psychology, 43, 1-12. http://dx.doi.org/10.1037/0012-1649.43.1.1

Howlett, E., Kees, J., \& Kemp, E. (2008). The Role of Self-Regulation, Future Orientation, and Financial Knowledge in Long-Term Financial Decisions. Journal of Consumer Affairs, 42, 223242. http://dx.doi.org/10.1111/j.1745-6606.2008.00106.x

Kees, J. (2011). Advertising Framing Effects and Consideration of Future Consequences. Journal of Consumer Affairs, 45, 7-32. http://dx.doi.org/10.1111/j.1745-6606.2010.01190.x

Kim, B. K., \& Zauberman, G. (2009). Perception of Anticipatory Time in Temporal Discounting. Journal of Neuroscience, Psychology, and Economics, 2, 91-101. http://dx.doi.org/10.1037/a0017686

Kinsley, C. H., \& Lambert, K. G. (2006). The Maternal Brain. Scientific American, 294, 72-79. http://dx.doi.org/10.1038/scientificamerican0106-72

Kinsley, C. H., \& Lambert, K. G. (2008). Reproduction-Induced Neuroplasticity: Natural Behavioral and Neuronal Alterations Associated with the Production and Care of Offspring. Journal of Neuroendocrinology, 20, 515-525. http://dx.doi.org/10.1111/j.1365-2826.2008.01667.x

Li, A. M., Peng, Y., \& Xiong, G. X. (2015). Are Pregnant Women More Foresighted?-The Effect of Pregnancy on Intertemporal Choice. Acta Psychologica Sinica, 47, 1360-1370. (In Chinese)

Liu, L., Feng, T., Chen, J., \& Li, H. (2013). The Value of Emotion: How Does Episodic Prospection Modulate Delay Discounting? PLoS ONE, 8, e81717.

http://dx.doi.org/10.1371/journal.pone.0081717

Loewenstein, G., \& Lerner, J. S. (2003). The Role of Affect in Decision Making. In R. J. Davidson et al. (Eds.), Handbook of Affective Science (pp. 619-642). Oxford: Oxford University Press.

Love, G., Torrey, N., McNamara, I., Morgan, M., Banks, M., Hester, N. W. et al. (2005). Maternal Experience Produces Long-Lasting Behavioral Modifications in the Rat. Behavioral Neuroscience, 119, 1084-1096. http://dx.doi.org/10.1037/0735-7044.119.4.1084

Lumpkin, G. T., \& Brigham, K. H. (2011). Long-Term Orientation and Intertemporal Choice in Family Firms. Entrepreneurship Theory and Practice, 35, 1149-1169.

http://dx.doi.org/10.1111/j.1540-6520.2011.00495.x

Madden, G. J., Petry, N. M., Badger, G. J., \& Bickel, W. K. (1997). Impulsive and Self-Control Choices in Opioid-Dependent Patients and Non-Drug-Using Control Patients: Drug and Monetary Rewards. Experimental and Clinical Psychopharmacology, 5, 256-262. http://dx.doi.org/10.1037/1064-1297.5.3.256

Matykiewicz, L., La Grange, L., Reyes, E., Vance, P., \& Wang, M. (1997). Adolescent Males, Impulsive/Aggressive Behavior, and Alcohol Abuse: Biological Correlates. Journal of Child and Adolescent Substance Abuse, 6, 27-37. http://dx.doi.org/10.1300/J029v06n02_02

Mercer, R. T. (2004). Becoming a Mother versus Maternal Role Attainment. Journal of Nursing Scholarship, 36, 226-232. http://dx.doi.org/10.1111/j.1547-5069.2004.04042.x

Moran, A. C., Sangli, G., Dineen, R., Rawlins, B., Yaméogo, M., \& Baya, B. (2006). Birth-Preparedness for Maternal Health: Findings from Koupéla District, Burkina Faso. Journal of Health, Population and Nutrition, 24, 489-497.

Muraven, M., \& Baumeister, R. F. (2000). Self-Regulation and Depletion of Limited Resources: Does Self-Control Resemble a Muscle? Psychological Bulletin, 126, 247-259.

http://dx.doi.org/10.1037/0033-2909.126.2.247

Peters, J., \& Büchel, C. (2010). Episodic Future Thinking Reduces Reward Delay Discounting through an Enhancement of Prefrontal-Mediotemporal Interactions. Neuron, 66, 138-148. http://dx.doi.org/10.1016/j.neuron.2010.03.026

Powdthavee, N. (2009). Think Having Children Will Make You Happy. The Psychologist, 22, 
$308-310$

Pyone, J. S., \& Isen, A. M. (2011). Positive Affect, Intertemporal Choice, and Levels of Thinking: Increasing Consumers' Willingness to Wait. Journal of Marketing Research, 48, 532-543. http://dx.doi.org/10.1509/jmkr.48.3.532

Rabinovich, A., Morton, T., \& Postmes, T. (2010). Time Perspective and Attitude-Behaviour Consistency in Future-Oriented Behaviours. British Journal of Social Psychology, 49, 69-89. http://dx.doi.org/10.1348/014466608X401875

Reynolds, B. (2006). A Review of Delay-Discounting Research with Humans: Relations to Drug Use and Gambling. Behavioural Pharmacology, 17, 651-667. http://dx.doi.org/10.1097/FBP.0b013e3280115f99

Sevin, E., \& Ladwein, R. (2008). To Start Being.... The Anticipation of a Social Role through Consumption in Life Transition: The Case of the First-Time Pregnancy. NA-Advances in Consumer Research, 35, 325-332

Shamosh, N. A., \& Gray, J. R. (2008). Delay Discounting and Intelligence: A Meta-Analysis. Intelligence, 36, 289-305. http://dx.doi.org/10.1016/j.intell.2007.09.004

Shapiro, L. (2007). The Embodied Cognition Research Programme. Philosophy Compass, 2, 338-346. http://dx.doi.org/10.1111/j.1747-9991.2007.00064.x

Soman, D., Ainslie, G., Frederick, S., Li, X., Lynch, J., Moreau, P. et al. (2005). The Psychology of Intertemporal Discounting: Why Are Distant Events Valued Differently from Proximal Ones? Marketing Letters, 16, 347-360. http://dx.doi.org/10.1007/s11002-005-5897-x

Steinberg, L., Graham, S., O’Brien, L., Woolard, J., Cauffman, E., \& Banich, M. (2009). Age Differences in Future Orientation and Delay Discounting. Child Development, 80, 28-44. http://dx.doi.org/10.1111/j.1467-8624.2008.01244.x

Strathman, A., Gleicher, F., Boninger, D. S., \& Edwards, C. S. (1994). The Consideration of Future Consequences: Weighing Immediate and Distant Outcomes of Behavior. Journal of Personality and Social Psychology, 66, 742-752. http://dx.doi.org/10.1037/0022-3514.66.4.742

Sun, Y., Li, S., Bonini, N., \& Su, Y. (2012). Graph-Framing Effects in Decision Making. Journal of Behavioral Decision Making, 25, 491-501. http://dx.doi.org/10.1002/bdm.749

Trope, Y., \& Liberman, N. (2003). Temporal Construal. Psychological Review, 110, 403-421. http://dx.doi.org/10.1037/0033-295X.110.3.403

Wang, X. T., \& Dvorak, R. D. (2010). Sweet Future: Fluctuating Blood Glucose Levels Affect Future Discounting. Psychological Science, 21, 183-188. http://dx.doi.org/10.1177/0956797609358096

Webley, P., \& Nyhus, E. K. (2006). Parents' Influence on Children's Future Orientation and Saving. Journal of Economic Psychology, 27, 140-164. http://dx.doi.org/10.1016/j.joep.2005.06.016 
Submit or recommend next manuscript to SCIRP and we will provide best service for you:

Accepting pre-submission inquiries through Email, Facebook, LinkedIn, Twitter, etc. A wide selection of journals (inclusive of 9 subjects, more than 200 journals)

Providing 24-hour high-quality service

User-friendly online submission system

Fair and swift peer-review system

Efficient typesetting and proofreading procedure

Display of the result of downloads and visits, as well as the number of cited articles

Maximum dissemination of your research work

Submit your manuscript at: http://papersubmission.scirp.org/

Or contact psych@scirp.org 